\title{
Several Thoughts on Alienated Labor Theory by Marx
}

\author{
Linlin Jiang ${ }^{1}$ \\ ${ }^{1}$ School of Marxism, Changchun University of Science and Technology, Changchun, China \\ Correspondence: Linlin Jiang, School of Marxism, Changchun University of Science and Technology, 7989 Wei \\ Xing Street, Changchun 130022, China. Tel: 86-431-8558-3045. E-mail: jl1@cust.edu.cn
}

Received: February 21, 2012 Accepted: March 26, $2012 \quad$ Published: June 1, 2012

doi:10.5539/ass.v8n7p100 URL: http://dx.doi.org/10.5539/ass.v8n7p100

\begin{abstract}
The alienated labor theory that was proposed by Marx in "Economic \& Philosophical Manuscripts of 1844" is the core of Marx's alienation concept and is also the most component of the theory of Marx. The alienated labor theory of Marx was gradually mature in the process of sublating the traditional alienation concept and its formation and development mainly underwent three phases and finally turned to become a complete theory system.
\end{abstract}

Keywords: alienated labor, alienation concept, Marx

\section{Sublation of Marx's Alienated Labor Theory to the Traditional Alienation Concept}

\subsection{Traditional Alienation Concept}

Ever since the emergence of modern humanism, the alienation concept has always been regarded as the fundamental method of research and evaluation of history by philosophers in the development process of western philosophy. Far away from the production relationship and historical reality, the alienation concept is an ethical concept of humanistic value and has the significance of social evaluation. Its premise is to assume that an ultimately eternal, absolute, valuable, ethical and humanistic scale is used to evaluate the history and it is the "supposed" tendency of social and historical development that it expresses, but it has not expressed the historical necessity of the society and the history and a historical principle and historical scale have not yet been formed. Whether the political alienation concept of Hobbes and Locke, or the absolute idea alienation concept of Hegel, and even the humanism alienation concept of Feuerbach, all basically follow a common logic, namely, firstly a "supposed" subject value presupposition and then the activities and results of the subject under a certain historical condition converted to something oppose to the subject per se and finally became the alien ruler and dominator. This sort of nonessential and alienated conversion, namely, alienation, can only be sublated through the subject and can finally return to itself. They are distinguished in that the subject of alienation differs: the alienation subject of Hobbes and Rousseau is "human" in its natural condition and the alienation subject of Hegel is the "absolute spirit", while the alienation subject of Feuerbach is the common "generic human".

\subsection{Sublation of Marx's Theory to the Traditional Alienation Concept}

Marx applied rich economics and history knowledge and discovered the starting point and foundation for his own new philosophy at the time when he pondered over and surpassed the theory of human nature by Feuerbach. That is to say, he regarded the free and conscious labor as the subject of alienation by linking together the reality of capitalism economic relationship and established the alienated labor theory. He converted the alienation theory from a basic historical concept to a specific method to evaluate the social and historical phenomena and finally found out the foundation for the proletariat to change the social reality.

The alienated labor theory is an original creation by Marx, but the alienation concept was not firstly created by Marx and his alienation concept mainly originated from his changing and surpassing of the thoughts by the predecessors. From a general viewpoint, the alienation theory of Marx mainly came from inheritance and development of the alienation thoughts by Rousseau, Hegel and Feuerbach.

In the first place, the alienation theory of Marx is inheritance and development of the alienation theory of Rousseau. In his "Social Contract Theory", Rousseau criticized all sorts of alienation phenomena in the autocracy society and expounded the freedom and equality of people, which offered abundant thought nourishment for formation of the alienation theory of Marx. 
In the second place, the alienation theory of Marx is the inheritance and criticism of the alienation theory of Hegel. The alienation theory of Marx was mainly established on the basis of sublation of the alienation concept of Hegel. Hegel realized the importance of labor to human being, thought that human being should overcome the nature with labor and made himself become the unrestrained existence in the process of labor. This was of great enlightenment to the alienated labor theory of Marx. It is exactly on the basis of a comprehensive criticism on the idealism alienation concept of Hegel and the entire philosophy that Marx proposed his own materialism dialectics and alienated labor theory.

In the third place, the alienation theory of Marx is the sublation and surpassing of the alienation theory of Feuerbach. The humanism alienation concept of Feuerbach is one of the direct sources for Marx's alienation theory. The religious alienation thought of Feuerbach affected Marx's view on the essence of human being in his early alienation theory. In "Economic \& Philosophical Manuscripts of 1844", Marx directly employed the technical term of "generic" by Feuerbach to describe the essential alienation, namely, alienation of human being and the generic essence of human being. In addition, it is exactly under the influences of Feuerbach that Marx thoroughly broke away from the idealism theory of Hegel and transferred to the materialism theory and became a real materialist.

\section{The Alienated Labor Theory Is the Core of Marx's Alienation Concept}

\subsection{The Formation of the Alienated Labor Theory}

A complete expression of the alienated labor theory of Marx was as early as in 1844, which was concentrated in the two books of "Abstract of 'Principles of Political Economy' by James Mill" and "Economic \& Philosophical Manuscripts of 1844". During that period, Marx was no longer a loyal believer of the philosophy of Hegel, but was deeply influenced by the humanism of Feuerbach. Nevertheless, due to the focus study on the national economics (old economics) between 1843 and 1844, Marx gradually walked out of Feuerbach and went deeply into the social and economic life to observe the history. This is especially obvious in "Economic \& Philosophical Manuscripts of 1844".

In "Economic and Philosophical Manuscripts of 1844", Marx put forth efforts to seek for the real subject of alienation from the actual social perspective. With this intension, he made a summary of the economic history. By means of his summary on the history and his reflection on the social and economic life reality, he found that the classic British economics school focused on labor but showed hostility to human; although Feuerbach discovered human, he failed to know about labor; the progress of Hegel was that he regarded labor as the essence of human, but the labor in his mind was nothing more than the abstract spiritual labor, namely, philosophical thinking activities. Different from the above three people, Marx criticize the actual economic relationship of capitalism by means of presupposing an ideal labor and an ideal human and changed the old national economics. The final conclusion he made was that, workers labor in capitalism was not the ideal labor, so he proposed the alienated labor. The essence of alienated labor was that, in the process of capitalism production, labors not only created products through labor, but also created multiple external existence one after another and also an independent power that was opposite to and alienated from themselves. With alienation of workers from their own labor products and alienation of workers from their own labor activities, the alienation of human and their own generic essence finally occurred. Workers produced capitalists through their own labor and human and human finally alienated from each other. However, there was only one path to overcome this alienation and realize returning of humanity, that is, to replace capitalism with communism. By then, there had finally had a real and reliable foundation for philosophers to observe and criticize the society and the history.

\subsection{The Alienated Labor Theory Is the Core of Marx's Alienation Concept}

A general survey of the life of Marx, it is found that he has always been employing the concept of alienation. In the view of Marx, all the fields of human activities might be alienated under certain conditions, so his alienation concept mainly includes religious alienation, political alienation, economic alienation and labor alienation. Labor alienation is not only the original creation of Marx, but also the core of his concept of alienation. It is exactly on the basis of alienated labor theory that Marx sublated the former alienation concepts and finally brought them into the religious alienation, political alienation and economic alienation concepts within the scope of philosophy. In the view of Marx, the latter were the derivative forms of labor alienation and labor alienation was the core and the ultimate source for all other forms of alienation. We may find the answer to this in the four provisions about alienated labor in Marx's early alienated labor theory.

The major content of the alienated labor of Marx originated from his comprehensive criticism on the national economics of the bourgeoisie and his starting point was to start out from the current economic fact, while the so-called current economic fact referred to the social phenomenon that the capitalists had a free possession of the 
labor fruits of workers, namely, alienated labor. In this sense, alienated labor played a role of economic scope here and Marx used this scope to expound the four provisions of alienated labor theory. In the first place, in the first provision of alienated labor theory, considering the production result, the labor of workers was alienated from their labor products. That is to say, workers lost their own essence in their alienated labor. "Things of animals became things of human beings, while things of human beings became things of animals." In the second place, in the second provision of the alienated labor theory, considering the production process, laborers were alienated from their labor activities. that is to say, "labor of workers was not a voluntary labor, but a forced and compulsory labor. Thus, it was not a means to satisfy the need of labor, but a means to satisfy needs outside the need of labor... The labor was not laborers themselves, but others; neither the labor belonged to laborers nor the laborers themselves belonged to themselves, but others." In the third place, in the third provision of the alienated labor theory, considering the generic essence of human beings, laborers were alienated from their generic essence. That is to say, under the alienated labor condition, reflection of human beings on their generic essence changed totally and the alienated labor made the nature, human beings and their activity functions as well as their life activities alienated from human beings and made generic human beings alienated from each other. Just as Marx said, "In that case, the alienated labor caused such results that the generic essence of human beings --whether the nature or the spiritual and generic capacity of human beings --- became the alienated essence of human beings and became a means to maintain his personal subsistence. The alienated labor made the body of human beings, the nature outside their body, their spiritual essence and their essence alienated from the human beings themselves." In the fourth place, in the fourth provision of the alienated labor theory, considering the relationship between human beings and human beings, they were alienated from each other. Marx pointed out in his analysis of the first three aspects of alienation, the direct result caused by this fact was that human beings were alienated from human beings. That is to say, "when human beings were opposite to themselves, they were also opposite to others. Anything that is applicable for the relationship between human beings and their own labor, their own labor products and themselves is also applicable for the relationship between human beings and others, others' labor and others' labor object."

From the analysis of the four aspects about alienated labor essence by Marx, we can find that, in essence, the alienated labor reflects the economic relations and political relations of exploiting and being exploited between capitalists and workers and the core of alienated labor is finally the alienation of human beings. As a matter of fact, alienation of labor is the basic starting point of Marx to criticize reality and observe the history and is the core and foundation $\mathrm{f}$ his alienation concept.

\section{The Alienated Labor Theory of Marx Is a Theory That Becomes Gradually Mature}

Formation of the alienated labor theory of Marx has a development process and its development generally has undergone three phases.

\subsection{The First Phase}

At the first phase prior to creation of the historical materialism, in his works of "On the Jewish Question", "The Critique of Hegel's Philosophy of Right" and so on that were written between 1842 and 1843, Marx still remained at the stage of study on alienation problems in spiritual life and political life. In "Economic \& Philosophical Manuscripts of 1844", although Marx definitely put forward the concept of alienated labor and regarded it as the core and basic starting point of his alienation concept, at that time, Marx still saw the generic essence and species being of human beings as the starting point to survey the realistic economic relationship.

\subsection{The Second Phase}

At the second phase of creation of historical materialism, in "The Holy Family", Marx showed obvious differences in his application of the concept of alienation. He no longer discussed the essence problem of human beings in an abstract and ideal way from the perspective of alienation, but laid particular emphasis on the actual life condition of workers and specific observation on the realistic circumstance. In "The Ideological State of Germany", his criticism thought and argumentation method had totally broken away from the logical framework of the abstract subject alienation theory and eradicated the residues of influences of Hegel and Feuerbach. The concept of alienated labor was still used, but the subject of alienation was no longer any abstract subject that was set in advance, but the actual individuals in the bourgeoisie society. Here, Marx's application of the concept of alienation was totally based on his analysis of the historical materialism in the human history and capitalistic society.

\subsection{The Third Phase}

At the third phase after formation of the historical materialism, namely, from the 1850 s to the 1860 s, in his 
works of "Economic Manuscript of 1857-1858", "Capital" and so on, Marx mainly expounded the essence of alienation on the basis of analyzing production relationship in capitalism. After he finished his critics and study on political economics, in his "Economic Manuscript of 1857-1858", he made a scientific analysis in how alienation came into being in the historical development and obtained the most poignant manifestation in the bourgeoisie society. In his "Capital", he criticized humanism factors and continued to use his thought about alienated labor that he proposed in his early years. Marx used "labor alienation" to represent the employment labor and to disclose separation of production means from workers as well as the fact that capitalists exploited workers. It can be said that, it is exactly in these works that Marx gradually sublated the social contract theory and the alienation theory from Hegel to Feuerbach and made his own alienated labor theory finally become a mature theory.

\section{References}

Chen, Xueyan. (2009). Analysis of Alienated Labor Theory by Marx and Pursuit of People in Emancipation. New West (Second Half Month), 2, 51-55.

Cheng, Miaomiao. Alienated Labor Theory of Marx and the Sense of Happiness of Human. Journal of Sichuan University of Science \& Engineering (Social Sciences Edition), 1, 93-97.

Li, Yan. (2010). Starting Point of Theory of Human by Marx: Alienated Labor. Journal of Inner Mongolia Finance and Economics College, 5, 78-83.

Marx. (2008). Economic \& Philosophical Manuscripts of 1844. Beijing: People's Publishing House.

Pan, Maojuan. (2011). Brief Discussion of Alienated labor --- Reading the Firsthand manuscript of "Economic \& Philosophical Manuscripts of 1844". Legal System and Society, 6, 67-72.

Shan, Wenli. (2010). Domestic Summary on Study of Alienated Labor Theory in "Economic \& Philosophical Manuscripts of 1844". Journal of Shanghai Business School, 6, 117-123.

Yan, Huijun. (2011). On the Relation between Human and Nature from the Alienated Labor Theory. Theory Horizon, 2, 103-109. 